\title{
An evolving understanding of nuclear receptor coregulator proteins
}

\section{Christopher J Millard, Peter J Watson, Louise Fairall and John W R Schwabe}

Henry Wellcome Laboratories of Structural Biology, Department of Biochemistry, University of Leicester, Leicester LE1 9HN, UK
Correspondence should be addressed to J W R Schwabe Email john.schwabe@le.ac.uk

\begin{abstract}
Nuclear receptors are transcription factors that regulate gene expression through the ligand-controlled recruitment of a diverse group of proteins known as coregulators. Most nuclear receptor coregulators function in large multi-protein complexes that modify chromatin and thereby regulate the transcription of target genes. Structural and functional studies are beginning to reveal how these complexes are assembled bringing together multiple functionalities that mediate: recruitment to specific genomic loci through interaction with transcription factors; recruitment of enzymatic activities that either modify or remodel chromatin and targeting the complexes to their chromatin substrate. These activities are regulated by post-translational modifications, alternative splicing and small signalling molecules. This review focuses on our current understanding of coregulator complexes and aims to highlight the common principles that are beginning to emerge.
\end{abstract}

\author{
Key Words \\ - nuclear receptors \\ - coregulator complexes \\ - coactivators \\ - corepressors \\ - chromatin \\ - transcriptional regulation
}

\section{Historical perspective}

Nuclear receptors are a large family of DNA-binding transcription factors that are recruited to specific DNA sequences in the genome and regulate the expression of genes in the proximity ( $<1$ million base pairs) of these sites. Nuclear receptors were first cloned in 1985. Over the next 10 years our understanding of their molecular mechanisms of action grew steadily and culminated with the determination of the structures of the DNA- and ligand-binding domains (reviewed in Wurtz et al. (1996), Khorasanizadeh \& Rastinejad (2001) and Brélivet et al. (2011)). These structures revealed much about how nuclear receptors recognise DNA and their cognate ligands, but did not immediately explain how their recruitment to DNA changes the rate of transcription of their target genes. In pursuit of this understanding, a great many studies sought to identify direct interactions between nuclear receptors and components of the general transcriptional machinery, based on the reasonable presumption that, like prokaryotic transcriptional activators, liganded nuclear receptors would directly recruit RNA polymerase II or associated proteins. These interactions turned out to be elusive, sparking a search for adapter proteins that would make bridging interactions to the general transcriptional machinery. Subsequently, it has become clear that coregulator proteins play a central role in the mediation of transcriptional regulation by nuclear receptors.

The first nuclear receptor coregulators were discovered through efforts to identify proteins that interact with either ligand-bound or unliganded nuclear receptors (Halachmi et al. 1994, Baniahmad et al. 1995, Cavaillès et al. 1995). This led to the identification of two classes of 
coregulator termed as coactivator proteins, such as SRC1 (Onate et al. 1995), and corepressor proteins, such as NCoR and SMRT (Chen \& Evans 1995, Hörlein et al. 1995). We now know that a very large number of proteins participate in the regulatory complexes recruited to nuclear receptors. Indeed more than 350 nuclear coregulators have been identified (http://www.NURSA.org). These proteins are a varied and diverse group that defy straightforward classification. However, it is important to consider some sort of definition for what is meant by coregulator proteins.

The broadest definition is that a coregulator is a protein that participates in a complex that is recruited to the genome by DNA-binding transcription factors, and through this recruitment, the complex regulates (up or down) the rate of transcription of one or more genes. These complexes often have a universal reach throughout the genome with an overarching role in the regulation of transcription (Lonard \& O'Malley 2012). It is important to recognise, however, that such a broad definition results in a huge number of proteins being classed as coregulator proteins. Indeed recent proteomic approaches have identified a frighteningly large number (thousands) of proteins as being involved in coregulator complexes (Foulds et al. 2013).

In this anniversary issue, we will attempt to draw out some of the general principles that have emerged concerning the mechanism of action of coregulator complexes, i.e. how they are recruited to specific genomic loci, what enzymatic activities they contain, how the complexes are targeted to chromatin, how coregulator complexes are assembled and finally how coregulators themselves may be regulated. This is not a comprehensive review and there will be an inevitable bias towards how structural biology has given us a better understanding of a small number of these complexes.

\section{Recruitment to specific genomic loci}

Coregulator complexes do not themselves contain constitutive components that direct sequence-specific recruitment to particular loci in the genome. However, recruitment to nuclear receptors and other sequencespecific transcription factors means that coregulator activity is directed to specific genomic loci leading to specific changes in gene regulation. Each coregulator complex can be recruited to many different transcription factors. Similarly, each transcription factor can often recruit many different coregulator complexes. Furthermore, the transcription factors themselves may be 'tethered' to other transcription factors rather than directly bound to DNA themselves. Taken together, this means that the specificity of action of coregulator complexes relies upon a complicated, but specific network of recruitment to various transcriptional regulators.

In the case of nuclear receptors, the presence or absence of a bound ligand determines which nuclear receptor coregulator complexes are recruited. Coregulator complexes that repress transcription are generally recruited to unliganded receptors or receptors bound to inverse agonists. In contrast, coregulator complexes that activate transcription are recruited to receptors bound to agonist ligands. The opposing action of these complexes has led to the widespread use of the terms corepressor and coactivator complexes. However, as we suggest later, it may be better to define complexes based on their mechanism of action rather than the transcriptional outcome.

The molecular mechanisms through which nuclear receptors recruit coregulator complexes are now wellestablished (reviewed in Watson et al. (2012b)). This is the result of the initial studies that identified critical sequence motifs in coregulator proteins that mediate liganddependent interactions with nuclear receptors, followed by crystal structures of the ligand-binding domains of nuclear receptors in complex with these interaction motifs. Remarkably, most of the coactivator complexes recruited to nuclear receptors do so through a conserved motif with the sequence LxxLL (the so-called NR box; Heery et al. 1997). Shortly after the identification of the NR box, an analogous sequence motif (LxxH/IIxxxI/L) was identified in corepressor proteins (Nagy et al. 1999, Hu \& Lazar 1999). This motif has been termed as the CoRNR box. Crystal structures have demonstrated that NR box and CoRNR box peptides adopt an $\alpha$-helical conformation that allows them to bind in the same hydrophobic groove on LBDs and therefore recruitment is mutually exclusive (Nolte et al. 1998, Xu et al. 2002, Wang et al. 2006, Phelan et al. 2010). Which class of coregulator that is recruited to the LBD depends upon the ligand-dependent positioning of the C-terminal helix (often termed helix 12) of the receptor (see Fig. 1).

An important feature of the NR and CoRNR sequence motifs is that they are located within the regions of the coactivator and corepressor proteins that are intrinsically disordered, i.e. do not have an intrinsically fixed structure. The helical structure appears to be formed only on interaction with the nuclear receptor ligand-binding domain. Strikingly, the intrinsic disorder of transcription factor interaction regions is common to many other transcription factor interaction motifs located in these

Published by Bioscientifica Ltd 
A

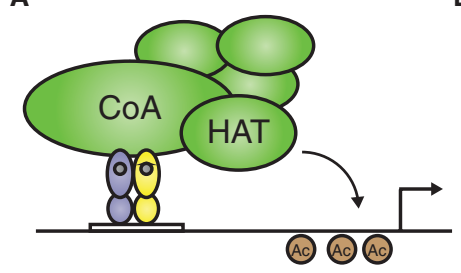

Increased transcription

D

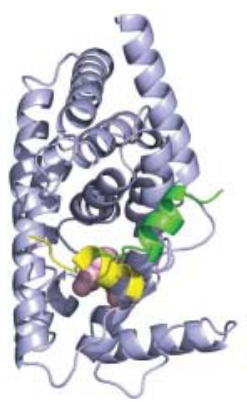

B

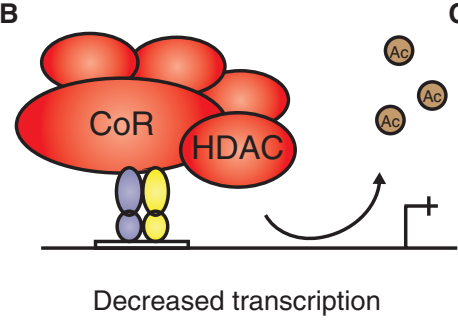

C

E
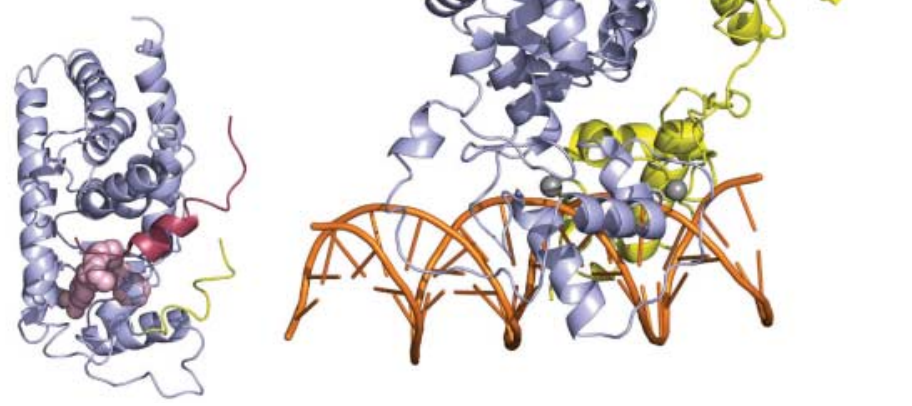

\section{Figure 1}

Coregulator complexes are recruited to the genome through DNA-binding transcription factors such as nuclear receptors. (A) Cartoon to illustrate the recruitment of coactivator complex to genes by liganded nuclear receptors, resulting in the acetylation of histone tails and an increase in the rate of transcription. (B) Nuclear receptors recruit corepressor complexes in the absence of ligand, resulting in the deacetylation of histone tails and decrease in the rate of transcription. (C) Crystal structure of PPAR $\gamma$ (light blue) and RXR $\alpha$ (yellow) heterodimer bound to DNA with an NCOA2

coregulator proteins (see for example, Ahmad et al. (2003) and Liu et al. (2007)). A consequence of this is that the entropic cost of forming a fixed structure in the bound complex results in a relatively low binding affinity, whilst preserving high specificity, between coregulators and their transcription factor partners. It also allows the coregulator to harbour many transcription factor-binding motifs in intrinsically disordered regions of the protein.

It remains to be seen whether full-length coregulators engage in more extensive contacts with DNA-bound nuclear receptors. The successful determination of crystal structures of full-length nuclear receptors (Chandra et al. 2008 , 2013) gives hope that some of these larger complexes may in due course become tractable targets for structure determination.

\section{Enzymes to modify chromatin}

The original nuclear receptor 'coregulator concept' encompassed the idea that if nuclear receptors did not directly interact with the general transcriptional machinery, perhaps there was some protein or protein complex that would act as an intermediary factor. We now know that such intermediary complexes, such as the peptide (green). Ligands rosiglitazone (for PPAR $\gamma$ and 9-cis retinoic acid (for $R X R \alpha$ are shown as purple sticks). Zinc atoms are shown as grey spheres (PDB code 3DZY (Chandra et al. 2008)). (D) Structure of PPAR $\gamma$ LBD (light blue) with the ligand rosiglitazone (pink) bound to a peptide from the SRC1 coactivator (green) (PDB code 2PRG (Nolte et al. 1998)). (E) Structure of PPAR $\alpha$ LBD (light blue) with the antagonist GW6471 (pink) bound to a peptide from the SMRT corepressor (red) (PDB code 1KKQ (Xu et al. 2002)). Helix 12 is highlighted in yellow in both ( $D$ and $E$ ).

mediator complex, do play an important role in transcriptional regulation. However, the majority of coregulator complexes do not simply act as bridging or assembly factors. Instead they act through bringing enzymatic activities to the locality of the site of their recruitment to the genome. These enzymes either covalently modify chromatin, or result in chromatin reorganisation. The discovery that coregulators act by targeting chromatin represented a highly significant breakthrough in our understanding of the mechanisms of gene regulation. In this review, we will focus mainly on complexes that add, remove and/or read post-translational modifications (PTMs) to nucleosome tails, and thereby influence chromatin accessibility through the further recruitment of other factors to chromatin.

The best-understood modifications include histone acetylation, methylation, phosphorylation and ubiquitylation. In addition to histone modification, DNA itself can be modified through methylation and hydroxymethylation of cytosine. In general, acetylation is associated with transcriptional activation whereas methylation can cause either activation or repression of transcription. Furthermore, histone tail modifications coexist so that particular combinations can bring particular functional outcomes.

Published by Bioscientifica Ltd 
For instance, the combined modifications H3K4me2/3+ H4K16ac are associated with transcriptionally active homeotic genes, whereas $\mathrm{H} 3 \mathrm{~K} 9 \mathrm{me} 3+\mathrm{H} 3 \mathrm{~K} 27 \mathrm{me} 3+\mathrm{CpG}$ $5-\mathrm{MeC}$ is a typical repression mark (Lindroth et al. 2004, Dou et al. 2005). Other combinatorial modifications have been shown to affect mitogen-stimulated transcription (H3S10ph + H3K9/14ac) and homeotic gene silencing (H3K27me3+H2AK119ub1) as well as chaperone association, maintenance of heterochromatin and inactivation of the X-chromosome (reviewed in Ruthenburg et al. (2007)).

The most intensely studied enzymes that form part of coregulator complexes and are essential in modifying chromatin are the histone acetylases/deacetylases and methylases/demethylases (Bannister \& Kouzarides 2011; Fig. 2). These are either termed as epigenetic 'writers' and 'erasers' depending on whether they add or remove modifications (Gardner et al. 2011, Cosgrove 2012).

Three classes of lysine deacetylases, class I and IIa HDACs, as well as several sirtuin proteins have been shown to act as coregulators of gene transcription. The class I HDACs are zinc-dependent hydrolases that are recruited into at least five different coregulator complexes. In isolation, these enzymes have very limited activity. Once assembled into the complex, the enzymes are activated in part through the binding of inositol phosphate activators (Watson et al. 2012a, Kelly \& Cowley 2013, Millard et al. 2013). Like the class I enzymes, class IIa HDACs are recruited to coregulator complexes such as the NCoR complex, but they can also be directly recruited to the genome by repressive transcription factors (Martin et al. 2007). Interestingly, despite their resemblance to class I HDACs, class IIa HDACs exhibit very little HDAC activity (Lahm et al. 2007). Consequently, the mechanism through which they influence transcription remains obscure, yet it is possible that they are activated in some way. Alternatively they may have a different, as yet unidentified, enzymatic activity. Sirtuins have also been shown to influence transcription and can be recruited to coregulator complexes. However, like the class IIa HDACs, this family of NAD-dependent deacetylases does not require obligate assembly into coregulator complexes and can be recruited directly to various transcription factors (Chalkiadaki \& Guarente 2012).

Like the class I HDACs, histone acetyl transferases (HATs) are often activated through assembly into larger protein complexes (Yang \& Seto 2007). The importance of assembly of HATs into coregulator complexes can be illustrated with Gcn5 (the yeast homologue of PCAF). Purified Gcn5 acetylates free histones but not those assembled into nucleosomes until the coregulator is associated with protein components of the SAGA complex (Grant et al. 1997). In another example, SRC1 is required as an adaptor to enhance the binding of CBP to the estrogen receptor (ER) and therefore direct its HAT activity to the chromatin (Sheppard et al. 2001, Waters et al. 2006).

Despite the lack of detectable primary sequence conservation, structures of the HAT domains from PCAF, p300/CBP and Esa1 show that they contain a structurally conserved central core (Clements et al. 1999, Yan et al. 2000, Liu et al. 2008, Yuan \& Marmorstein 2013). Unlike that of the class I HDACs, the catalytic domains of HAT enzymes are often located within larger proteins that contain multiple additional domains. In particular, adjacent bromodomains have been shown to be the important determinants of substrate specificity (Lee \& Workman 2007, Zeng et al. 2008). A recent crystal structure of the p300 central region has shown that the HAT domain is tightly associated with the adjacent bromo, PHD and RING finger domains, explaining how the accessory domains direct the HAT activity to correct substrates (Delvecchio et al. 2013).

Methyl groups can be reversibly added to proteins on arginine and lysine residues by peptidylarginine methyltransferases (PRMTs) and lysine methyltransferases respectively. PRMTs require their activity to be directed by accessory proteins, whereas the lysine methyltransferases have some intrinsic targeting ability. For instance, PRMT5 contains only a single domain that must form a stable hetero-octameric complex with the WD40 repeat containing MEP50 for the direction of methlytransferase to its H4 substrate (Antonysamy et al. 2012). In contrast, the lysine methyltransferase NSD3 has several domains in addition to the SET domain to direct its own methyltransferase activity; the fifth PHD finger and the $\mathrm{C} 5 \mathrm{HCH}$ domain of NSD3 provide the molecular basis for the recognition of unmodified lysine 5 on histone $\mathrm{H} 3$ (He et al. 2013). However, while some of the intrinsic targeting activity comes from NSD3 itself, the enzyme associates with the demethylase LSD2 and methyltransferase G9a to establish a pattern of methyl marks on histone tails (Shi et al. 2006).

A family of multi-domain proteins known as lysine demethylases remove the methylation marks placed on coregulators (Cloos et al. 2008). LSD1 and LSD2 are highly related sister enzymes, but assemble into separate protein complexes through the presence or absence of a tower domain. LSD1 is incorporated into the CoREST complex through this 'stalk-like' tower domain which forms an

Published by Bioscientifica Ltd 
A

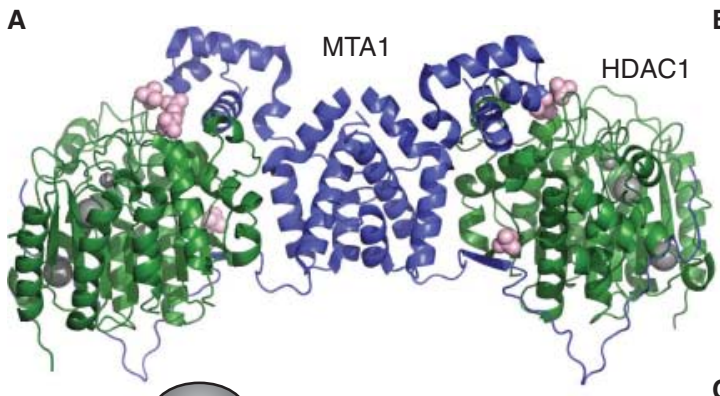

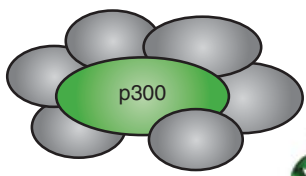

Histone acetyltransferase from SRC1 complex

C

Histone deacetylase from the NuRD complex

D

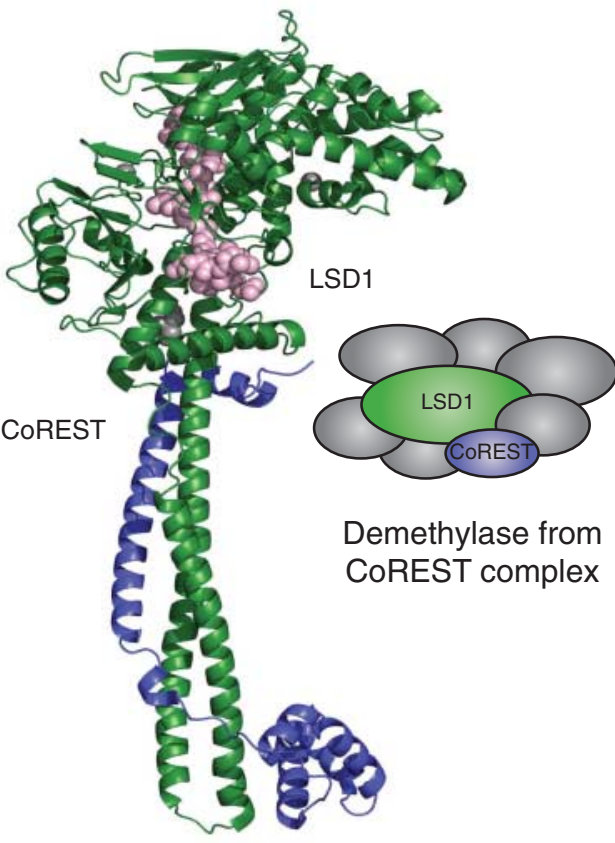
with hub protein
Methyltransferase

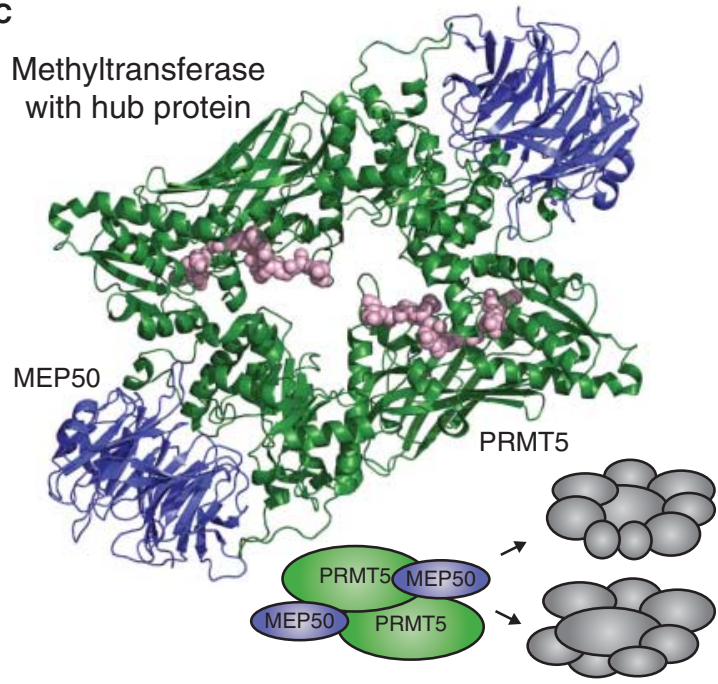

E

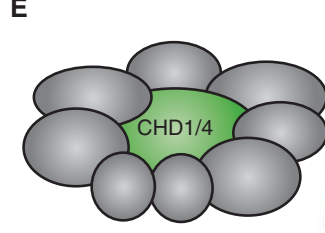

ATP helicase (homologue of CHD4) from the NuRD complex
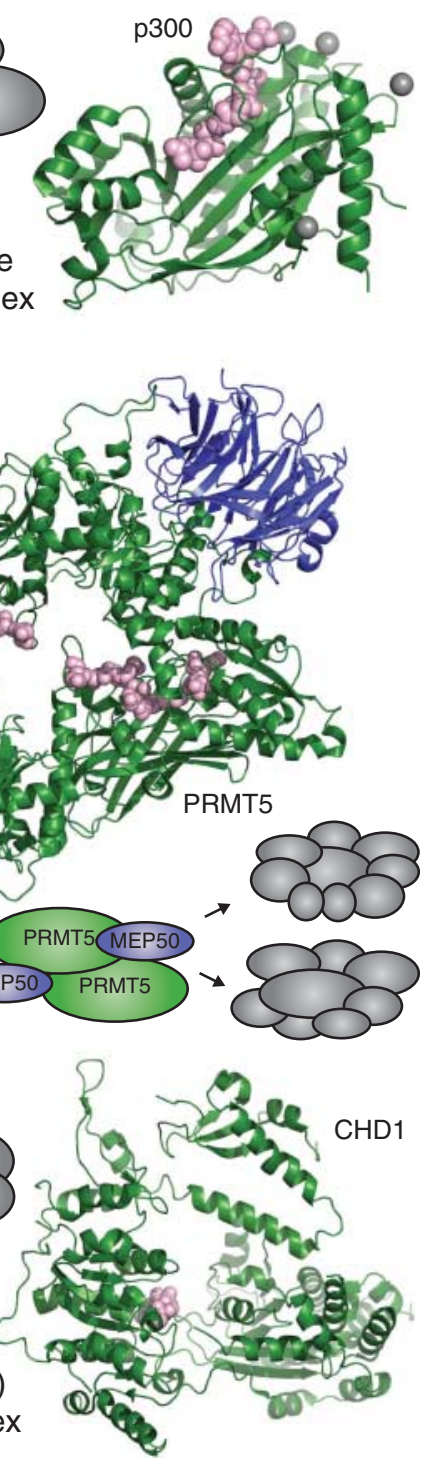

Figure 2

Crystal structures of coregulator proteins possessing enzymatic activity with schematic representations of their cognate complexes. (A) The histone deacetylase HDAC1 bound to an MTA1 dimer, with sulphate molecules bound at the positively charged inositol phosphate-binding interface between the two proteins (PDB code 4BKX (Millard et al. 2013)). (B) The histone acetyltransferase $\mathrm{p} 300$ with the inhibitor Lys-CoA (PDB code 3BIY (Liu et al. 2008)). In all panels: enzymes are shown in green, accessory proteins in blue, metal ions in grey and histone tails/cofactors as pink

elongated coiled coil with CoREST (Fig. 2D; Yang et al. 2006). The demethylase activity of its amine oxidase domain is further directed by the adjacent SWIRM1 domain (Stavropoulos et al. 2006). In contrast, LSD2 is recruited through an alternate mechanism that does not require the tower domain, as shown by the crystal structure of LSD2:NPAC:H3 (Fang et al. 2013). NPAC is a putative $\mathrm{H} 3 \mathrm{~K} 36 \mathrm{me} 3$-binding protein and may provide

spheres. (C) The arginine methytransferase PRMT5 in complex with the adaptor protein MEP50 with bound AdoMet analogue and $\mathrm{H} 4$ peptide (PDB code 4GQB (Antonysamy et al. 2012)). (D) The demethylase LSD1 with corepressor CoREST. A histone H3 peptide covalently attached to FAD is bound in the active site of LSD1 (PDB code 2UXN (Yang et al. 2007)). (E) The ATPase domain from CHD1 with a bound nucleotide (PDB code 3MWY (Hauk et al. 2010)).

a mechanism for targeting LSD2 to this histone modification.

ATP-dependent helicases are key components of many coregulator complexes that both remodel chromatin and detach other bound proteins to allow greater access of the transcriptional machinery to the DNA. The ATPase activity of these proteins is directed both through adjacent domains and partner proteins. Each ATPase has

Published by Bioscientifica Ltd 
some intrinsic chromatin-targeting ability by virtue of adjacent domains, which include bromodomains (targets acetylated lysines), CHD and PHD domains (targets methylated lysines) and HAND-SANT-SLIDE domains (targets unmodified histone tails) (Clapier \& Cairns 2009). Crystal structures, cryo-electron microscopy and site-directed photochemical mapping studies on ISW1a lacking its ATPase domains show how these adjacent domains could act as a 'protein ruler' and therefore set the spacing between two adjacent nucleosomes (Yamada et al. 2011). The crystal structure of the eukaryotic CHD1 shows that the ATPase domain interacts with, and is regulated by, the adjacent double chromodomain (Hauk et al. 2010). Further ATPases ISWI and CHD4 show distinct nucleosome-binding and mobilisation activities that are directed by these associated domains (Brehm 2000). In addition, partner coregulator proteins such as the methyl-CpG binding domain protein MDB2 can direct the helicase activity of CHD4 to methylated DNA (Zhang et al. 1999, Ramírez et al. 2012).

\section{Chromatin targeting}

A striking feature of many of the enzymes associated with coregulator complexes is the apparent lack of specificity for particular substrates. It has become clear that the specificity of these complexes is rarely determined by the catalytic subunit of the enzyme but is in fact promoted by other domains, present in the coregulator holo-complex, that drive the specificity of interaction. These domains can be located in the same protein as the catalytic subunit or be located in a different subunit of the coregulator complex.

The recruitment of coregulator complexes to the nucleosome is a key step in transcriptional regulation. Many of the multi-domained coregulator proteins contain chromatin-binding modules and a number have been structurally characterised with peptides corresponding to modified and unmodified histone tails. The structure of the bromodomain of GCN5 bound to a peptide corresponding to an acetylated histone $\mathrm{H} 4$ peptide shows clearly the mode of recognition and specificity (Owen et al. 2000). The main determinant of the specificity of acetyl lysine recognition is through a number of aromatic residues that form a hydrophobic binding pocket on GCN5 (Fig. 3A). A histidine binding in another hydrophobic pocket confers further specificity.

In the case of the binding of the chromodomain of HP1 to a peptide corresponding to histone H3 methylated at Lys9, the recognition is primarily provided by the methyl group binding in a pocket of three aromatic residues (Fig. 3B; Jacobs \& Khorasanizadeh 2002, Nielsen et al. 2002). The major determinant of the specificity appears to be an alanine that is buried in a deep pocket that could not be occupied by any other amino acid.

WD40 domains are common motifs that are present in chromatin-binding proteins, but are distinct from bromodomains and chromodomains. The structure of the WD40 domain polycomb protein EED bound to a peptide corresponding to tri-methylated Lys 27 from histone $\mathrm{H} 3$ shows the tri-methyl group in an aromatic cage formed by three hydrophobic residues (Fig. 3C; Margueron et al. 2009). The structure of the WD40 domains from RBAP46, and its Drosophila homologue p55 interacting with an $\mathrm{H} 4$ peptide, shows an alpha helical structure for the peptide bound to a pocket in the side of the WD40 domain. The structure of RBAP46 suggests that the histone tail is partially unfolded by the binding event (Fig. 3D; Murzina et al. 2008, Song et al. 2008).

More recently structures of chromatin-binding proteins bound to nucleosomes have been obtained and these have provided insight into the mechanism of coregulator complex recruitment. The BAH domain of SIR3 and WD40 domain from the chromatin factor RCC1 both show significant interactions with the histone octamer (Fig. 3E and F). The BAH domain of SIR3 interacts mainly with the tail of $\mathrm{H} 4$ that becomes folded upon binding. The conformational change promotes interaction of the $\mathrm{H} 4$ tail with the nucleosomal DNA. The BAH domain also interacts with histones H2B and H3 (Armache et al. 2011, Wang et al. 2013). The affinity of binding of the BAH domain is increased when the N-terminus is acetylated (Arnaudo et al. 2013, Yang et al. 2013). In addition to extensive contacts to the H2A-H2B histone dimer, the WD40 domain of RCC1 interacts directly with the nucleosomal DNA (Makde et al. 2010).

Many of the coregulator proteins have adjacent domains that contribute to the specificity. For example the methylase JMJD2A has a double tudor domain C-terminal to the catalytic domain. In JMJD, two tudor domains are interdigitated so that part of each motif forms one domain that binds to histone $\mathrm{H} 3$ trimethylated at lysine 4 (Huang et al. 2006). The ADD domain of the heterochromatin protein ATRX has two rigidly oriented domains that interact with two different modifications on the tail of H3. The PHD zinc finger interacts with unmodified H3K4 and the GATA-like zinc finger and its linker with the H3K9Me3 (Eustermann et al. 2011).

Published by Bioscientifica Ltd 
A

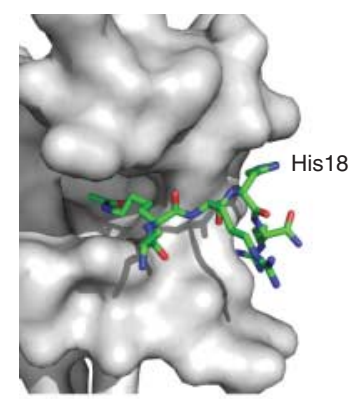

H4Lys16Ac - GCN5 bromodomain
B

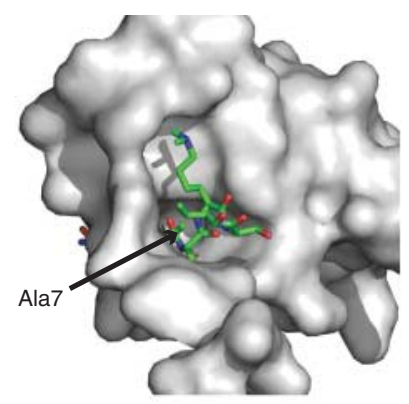

H3Lys9Me - HP1 chromodomain
C

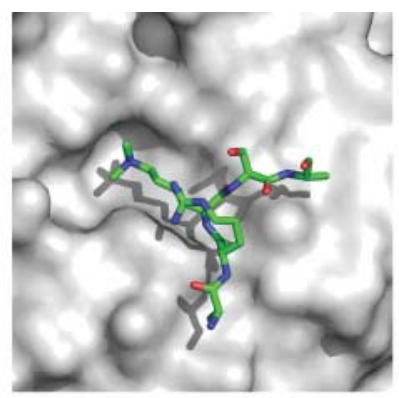

H3Lys27Me3 - EED WD40 domain
D

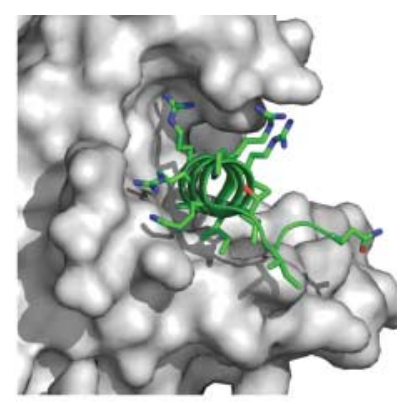

Histone H4 - RBAP46 WD40 domain

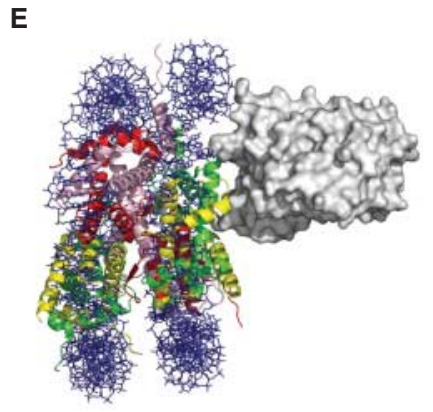

Nucleosome - RCC1 WD40 domain
$\mathbf{F}$

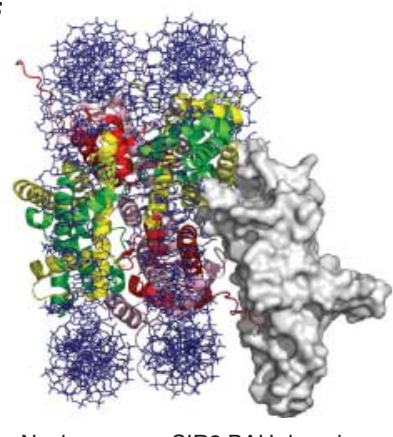

Nucleosome - SIR3 BAH domain

Figure 3

Space filling representations of chromatin binding modules. (A) Histone $\mathrm{H} 4$ acetylated at Lys16 bound to bromodomain of GCN5 (grey) (PDB code 1E6I (Owen et al. 2000)). (B) Histone H3 methylated at Lys9 bound to chromodomain of HP1 (grey) (PDB code 1GUW (Nielsen et al. 2002)). (C) Histone $\mathrm{H} 3$ tri-methylated at Lys27 bound to the WD40 domain of EED (grey) (PDB code 3IIW (Margueron et al. 2009)). (D) Histone H4 tail

\section{Assembling complexes}

It has become abundantly clear that most if not all coregulator proteins involved in regulating transcription operate in the form of higher order complexes. As we explore these both structurally and functionally, it emerges that the main reason for this is that multiple functionalities have to be coordinated in order to bring about the required transcriptional outcome. The proteinprotein interactions involved in assembling these complexes seem to come in two flavours: high affinity interactions that contribute to obligate and stoichiometric core complexes, and much weaker, transient interactions such as recruitment interactions with transcription factors. Indeed, mass spectrometry has shown that the core of coregulator complexes containing the enzymatic activity is relatively stable, as demonstrated by high resistance to salt treatment, whereas transcription factors preferentially exist in rapid equilibrium (Bantscheff et al. 2011, Joshi et al. 2013). Printed in Great Britain (amino acids 16-41) bound to the WD40 domain of RBAP46 shown in grey (PDB code 3CFS (Murzina et al. 2008)). (E) WD40 domain of RCC1 (grey) bound to a nucleosome (DNA blue, H2A green, $\mathrm{H} 2 \mathrm{~B}$ yellow, $\mathrm{H} 3$ pink and $\mathrm{H} 4$ red) (PDB code 3MVD (Makde et al. 2010)). (F) BAH domain of SIR3 (grey) bound to a nucleosome (DNA blue, H2A green, $\mathrm{H} 2 \mathrm{~B}$ yellow, $\mathrm{H} 3$ pink and $\mathrm{H} 4$ red) (PDB code 3 TU4 (Armache et al. 2011)).

Electron microscopic analyses of several coregulator complexes, including the SAGA, mediator and PRC2 complexes, have revealed that these complexes, despite containing multiple proteins with regions predicted to be intrinsically disordered, exhibit surprisingly rigid and uniform architectures when fully assembled (Wu et al. 2004, Cai et al. 2012, Ciferri et al. 2012).

The assembly of the obligate core complexes is frequently co-ordinated by hub/platform proteins (Fig. 4) and these mediate interaction with nuclear receptors and other transcription factors (Bulynko \& O'Malley 2011). The creation of an active complex through this modular assembly ensures flexibility to complete tasks that range from remodelling of chromatin to modification of individual residues in order to bring about a coordinated response. For example, the deacetylase activity of HDAC3 is directed by hub protein SMRT and two further core proteins TBL1 and GPS2, which together target the HDAC activity to chromatin, resulting in transcriptional

Published by Bioscientifica Ltd 


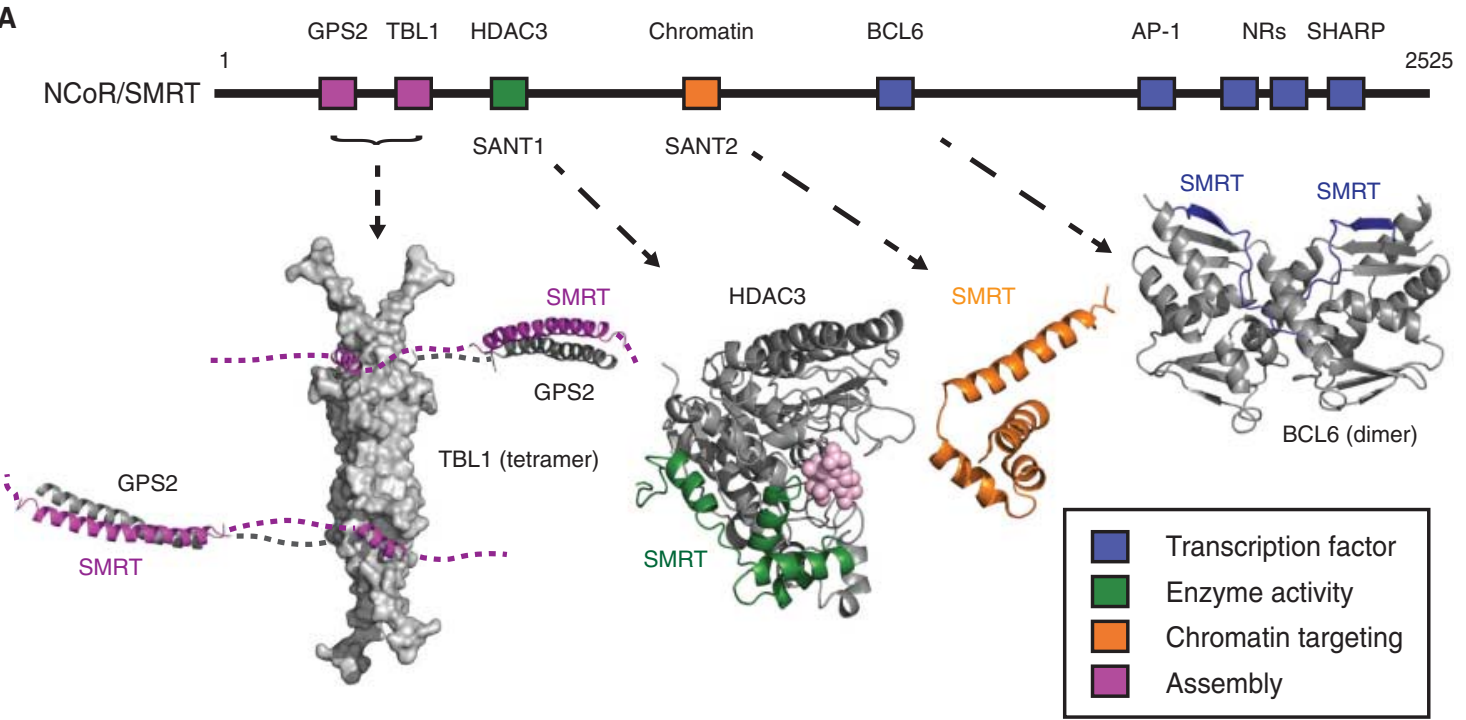

B

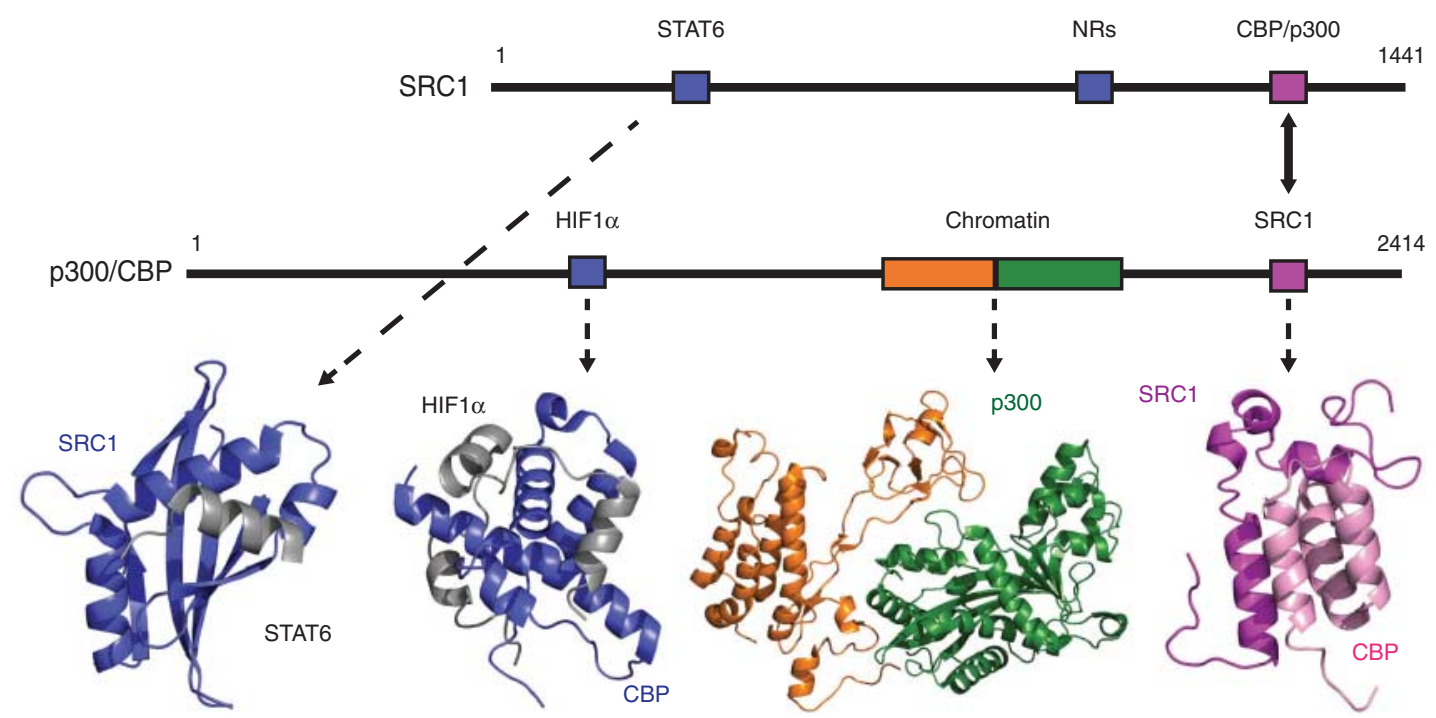

Figure 4

Schematic domain structures of coregulator proteins (A) NCOR/SMRT and (B) SRC1 and p300/CBP. A number of selected interaction domains are colour coded with respect to the role of the domains in the assembled complex. Structures of these domains are shown with the various interacting partners (GPS2/SMRT and TBL1 (PDB codes 2L5G and 2XTC

repression (Oberoi et al. 2011). Once assembled, these coregulator complexes then have the full repertoire of recognition modules and enzymatic factors required to enhance or repress nuclear receptor-mediated transcription.

Dimers and tetramers are a common feature of coregulator core complexes. Many of the enzymatic properties within the complex are duplicated and this allows these multivalent activities to be spread to a larger region of chromatin or to more than a single nucleosome.
(Oberoi et al. 2011)), HDAC3/SMRT and $\mathrm{IP}_{4}$ (pink spheres) (PDB code $4 A 69$ (Watson et al. 2012a)), SMRT-SANT2 (PDB code 2ltp), BCL6/SMRT (PDB code 1r2b (Ahmad et al. 2003)), STAT6/SRC1 (PDB code 1OJ5 (Razeto et al. 2004)), HIF1a/CBP (PDB code 1l8c (Dames et al. 2002)), p300 (PDB code 4bhw (Delvecchio et al. 2013)) and SRC1/CBP (PDB code 2c52 (Waters et al. 2006))).

Tetramerisation of the core of the SMRT repression complex is mediated by the amino-terminal domain of TBL1, which recruits two copies of SMRT and two copies of GPS2, resulting in the formation of a large coregulator complex (Oberoi et al. 2011). The corepressor scaffold protein TUP1 (Schizosaccharomyces pombe) shares a common architecture with TBL1 and both have an amino-terminal tetramerisation domain and a C-terminal WD40. The TUP1 tetramer may oligomerise further to form an extended fibre and therefore accomplish

Published by Bioscientifica Ltd 
long-range transcriptional repression (Matsumura et al. 2012). In a further example, the nucleosome-remodelling enzyme ISWI dimerises when it binds to nucleosomes (Blosser et al. 2009, Racki et al. 2009). Dimerisation improves catalysis and is key to the bidirectional sliding of nucleosomes.

\section{Two-faced coregulators}

Historically, coregulators and coregulator complexes have been placed into either the category of coactivator or corepressor, but there are a growing number of scenarios where there is significant disagreement over this classification. Coregulators were originally isolated and defined based on the outcome of single cell-based assays; coactivators are proteins that enhance transcription and corepressors are proteins that repress transcription. There are a number of cases where proteins historically classified as either coactivator or corepressor have been shown to have the opposite effect. For instance, RIP140 appeared to be an inverse coregulator in that it interacts with ligandbound $\mathrm{ER} \alpha$ yet represses transcription (Cavaillès et al. 1995). Surprisingly, later studies have shown that RIP140 has both coactivator and corepressor properties, which allow it to function as a key and central regulator in development, inflammation and metabolism (reviewed in Nautiyal et al. (2013)).

The classical coregulators SRC1 and NCoR/SMRT have also been shown, under certain circumstances, to apparently act in the opposite fashion to their original classification. SRC1, which is most often reported to enhance transcription, can also behave as a corepressor with thyroid hormone receptor $(T R)$ in thyrotropin gene expression (Jeyakumar et al. 1997, Weiss et al. 1999). NCoR/SMRT, which are usually defined as corepressors, can also serve as either TR-dependent activators or repressors, depending on the TR target promoter (Tagami et al. 1997, Berghagen et al. 2002). It is apparent that there are still many questions concerning the underlying mechanisms through which these coregulators function. However, many apparently contradictory findings may be explained through the requirement for rapid acetylation/ deacetylation cycling on promoters of nuclear receptorregulated genes (Burakov et al. 2002, Métivier et al. 2003, Wang et al. 2005).

In some cases, the switch from corepressor to coactivator can be fashioned by the surrounding cellular environment. SMRT can act as a coactivator for full agonist-dependent ER $\alpha$ activation in HeLa and MCF-7 cells; however, SMRT reverts to its corepressor role in
HepG2 cells, suggesting that the positive effects are celltype specific (Peterson et al. 2007). In another example, TIF2/GRIP1 is reported as a coactivator for the glucocorticoid receptor and TR, but can act as a repressor when interacting with TR in U2OS cells at the Col3A response element (Rogatsky 2001). This cell-type specificity has been attributed to the availability of gene-specific and cell-dependent factors. These examples highlight that it is important to discuss coregulators as a 'selective coactivator' or 'selective corepressor' with reference to the cellular environment to clarify the role in that particular cell type.

\section{Regulating the coregulators}

Coregulator proteins are, of course, targets of many other regulatory processes. One of the mechanisms for regulating coregulator properties is through the addition or removal of PTMs. These changes to individual surface residues can promote or ablate interactions, altering the composition of protein complexes and allowing the coregulator to rapidly transmit environment signals. In addition, the properties of coregulators can be changed through alternative splicing, proteolytical processing and through the presence of small molecule ligands.

Methylation of several coregulator proteins has been shown to profoundly change their activity. For instance, unmodified RIP140 represses transcription of RAR $\beta 2$, but upon arginine methylation by the methyltransferase PRMT1, this repressive activity is lost (Mostaqul Huq et al. 2006). Arginine methylation has also been shown to affect the activity of further coregulators such as PGC1 $\alpha$ (Teyssier $e t$ al. 2005) and CBP/p300 (Xu et al. 2001).

Coregulators have also been shown to be regulated by phosphorylation. For example, RIP140 has 11 phosphorylation sites and modification at these sites influences the recruitment of HDACs to the complex (Gupta et al. 2005). In another example, the self-association of SMRT is inhibited upon phosphorylation by the kinase ERK2, causing release from its nuclear receptor partners, and induces a subcellular redistribution of SMRT (Varlakhanova et al. 2011).

Intriguingly, complexes that regulate the acetylation of chromatin have themselves been reported to be regulated by acetylation. For instance, MTA1 is normally classed as a corepressor due to its association with the NuRD repression complex, but can function as a coactivator to stimulate breast cancer amplified sequence 3 (BCAS3) if acetylated at K626. (Gururaj et al. 2006). MTA1 has been suggested to dissociate from its corepressor

Published by Bioscientifica Ltd 
complex on acetylation and form an association with Pol II, hence activating transcription.

Ubiquitin and small ubiquitin-related modifier (SUMO) are short polypeptides that are covalently but reversibly attached to proteins that dynamically regulate their localisation and activity (Gill 2004). p300 and CBP have two tandem SUMO sites in their CRD1 domains, and before modification, these proteins facilitate transcriptional activation. However, following SUMOylation, this domain recruits HDAC6 and acts to repress transcription (Girdwood et al. 2003). As well as affecting the activity of coregulators, SUMO modification can retain or direct proteins to different compartments within the cell. SUMOylation of SRC1 was shown to stabilise the association of the progesterone receptor with SRC1 (Chauchereau et al. 2003). Furthermore, SUMOylated SRC1 is retained in the nucleus resulting in enhanced transcription.

PTMs have been shown to act in combination. For example, SRC3 requires phosphorylation followed by the addition of sequential ubiquitin monomers for full activation. However, a sufficiently long ubiquitin chain will signal for the protein for destruction (Wu et al. 2007). This example of dual modification opens up the possibility of a coregulator 'PTM code' and suggests that many other marks may be used in combination to influence coregulator function (Lonard \& O'Malley 2007). The scope for subtly changing the properties of coregulators through combinations of PTMs has been highlighted through studies on histones (Strahl \& Allis 2000, Gardner et al. 2011). It is likely that each individual PTM that has a distinct function may be added to other PTMs to build up this code and massively broaden the functional repertoire of coregulators.

In addition to PTM, proteolytic processing can change the molecular properties of coregulators. A proteolytically cleaved form of SRC1 has altered molecular properties to full length SRC1 and can actively prevent apoptosis (Han et al. 2012). This SRC1 C-terminally truncated protein interacts with procaspase 8 to prevent activational processing and in this way enhances endometriosis progression.

Differential splicing of coregulators is a further mechanism through which function of coregulator can be regulated. An intriguing example of this is that splice variants change the affinity of NCoR for the nuclear receptors that regulate adipogenesis. The splice variants appear to exert opposing effects on adipocyte differentiation; one splice variant $\mathrm{NCoR} \omega$ inhibits adopogenesis, while another NCoR $\delta$ promotes adipogenesis (Goodson et al. 2011). There are at least seven splice variants of NCoR that have been characterised, and these will undoubtedly lead to differential susceptibility to PTMs as well as modulating different interactions with partner proteins (Mottis et al. 2013).

A recent surprise in the field was the discovery that inositol phosphates mediate the interaction between HDAC3 and SMRT (Watson et al. 2012a). Ins $(1,4,5,6) \mathrm{P}_{4}$ binds at the interface between the two proteins and enhances HDAC activity in class I HDAC complexes (Millard et al. 2013). Inositol phosphates have also been shown to stimulate the SWI/SNF complex and therefore seem to have multiple roles in the regulation of chromatin remodelling and transcription (Shen et al. 2003, Steger et al. 2003).

\section{Perspectives}

In this review, we have tried to highlight some of the common principles through which coregulator proteins function. The majority of coregulator proteins do not function in isolation, but are assembled into large complexes so as to bring multiple functionalities together. In the broadest terms, these functionalities fall into four classes: i) interactions with transcription factors that recruit the complexes to specific genomic loci; ii) recruitment of enzymatic subunits which when targeted to chromatin either bring about changes in the modification state of the chromatin or lead to chromatin remodelling; iii) interactions with chromatin that are either responsible for recognising the modification state of the chromatin or act as substrate presentation modules facilitating the enzymatic activity of the complex and iv) assembly domains that hold the coregulator complexes together allowing the different functionalities to coexist in one complex molecular machine (Fig. 4).

Despite these common principles, the biological roles and detailed mechanisms of action of the majority of coregulator complexes are yet to be fully understood. One of the biggest questions concerns if (and how) the activities of all these diverse complexes are coordinated? Is there some order of activity? Do these complexes need to be recruited sequentially? Or is it simply a stochastic process? Another important issue concerns the dynamics of recruitment of these complexes to the genome. Several studies have suggested that the residence times of nuclear receptors are very short (review in Stavreva et al. (2012)). How do these residence times relate to the recruitment of coregulator complexes? Does complex recruitment stabilise the transcription factor association with chromatin?

Published by Bioscientifica Ltd 
Furthermore, how should we think about the action of these complexes in the complete chromatin landscape? For example, HDACs are classical repressors of transcription, yet they appear to be more abundant on primed promoters and active genes (Wang et al. 2009). Do they perhaps have some role during transcriptional elongation?

Perhaps the most intriguing outstanding issue concerns the emerging evidence that interaction with RNA is an important activity of a number of coregulator complexes. In some cases, it appears that specific long non-coding lncRNAs, such as SRA, play a role in the assembly of coregulator complexes. In other instances, there is evidence to suggest that IncRNAs play a role in recruitment to the genome (Kugel \& Goodrich 2012). There is also evidence that there may be RNA-mediated cross-talk with the splicing machinery. The mechanism and biological significance of these interactions remain to be elucidated.

Finally, it is important to note that the driver for understanding the mechanisms and roles of coregulator complexes goes beyond the simple desire for a fundamental understanding, given that there is increasing evidence that compounds which target epigenetic modifiers can be useful in a variety of therapeutic circumstances (Gal-Yam et al. 2008, Helin \& Dhanak 2013).

\section{Declaration of interest}

The authors declare that there is no conflict of interest that could be perceived as prejudicing the impartiality of the review reported.

\section{Funding}

This work was supported by the Wellcome Trust (grant number WT085408) and the BBSRC (grant number 10867).

\section{References}

Ahmad KF, Melnick A, Lax S, Bouchard D, Liu J, Kiang C-L, Mayer S, Takahashi S, Licht JD \& Privé GG 2003 Mechanism of SMRT corepressor recruitment by the BCL6 BTB domain. Molecular Cell 12 1551-1564. (doi:10.1016/S1097-2765(03)00454-4)

Antonysamy S, Bonday Z, Campbell RM, Doyle B, Druzina Z, Gheyi T, Han B, Jungheim LN, Qian Y, Rauch C et al. 2012 Crystal structure of the human PRMT5:MEP50 complex. PNAS 109 17960-17965. (doi:10.1073/pnas. 1209814109)

Armache K-J, Garlick JD, Canzio D, Narlikar GJ \& Kingston RE 2011 Structural basis of silencing: Sir3 BAH domain in complex with a nucleosome at 3.0 A resolution. Science 334 977-982. (doi:10.1126/ science. 1210915

Arnaudo N, Fernández IS, McLaughlin SH, Peak-Chew SY, Rhodes D \& Martino F 2013 The N-terminal acetylation of Sir3 stabilizes its binding to the nucleosome core particle. Nature Structural \& Molecular Biology 20 1119-1121. (doi:10.1038/nsmb.2641)
Baniahmad A, Leng X, Burris TP, Tsai SY, Tsai MJ \& O'Malley BW 1995 The tau 4 activation domain of the thyroid hormone receptor is required for release of a putative corepressor(s) necessary for transcriptional silencing. Molecular and Cellular Biology 15 76-86.

Bannister AJ \& Kouzarides T 2011 Regulation of chromatin by histone modifications. Cell Research 21 381-395. (doi:10.1038/cr.2011.22)

Bantscheff M, Hopf C, Savitski MM, Dittmann A, Grandi P, Michon A-M, Schlegl J, Abraham Y, Becher I, Bergamini G et al. 2011 Chemoproteomics profiling of HDAC inhibitors reveals selective targeting of HDAC complexes. Nature Biotechnology 29 255-265. (doi:10.1038/ nbt.1759)

Berghagen H, Ragnhildstveit E, Krogsrud K, Thuestad G, Apriletti J \& Saatcioglu F 2002 Corepressor SMRT functions as a coactivator for thyroid hormone receptor $\mathrm{T} 3 \mathrm{R} \alpha$ from a negative hormone response element. Journal of Biological Chemistry 277 49517-49522. (doi:10.1074/ jbc.M209546200)

Blosser TR, Yang JG, Stone MD, Narlikar GJ \& Zhuang X 2009 Dynamics of nucleosome remodelling by individual ACF complexes. Nature 462 1022-1027. (doi:10.1038/nature08627)

Brehm A $2000 \mathrm{dMi}-2$ and ISWI chromatin remodelling factors have distinct nucleosome binding and mobilization properties. EMBO Journal 19 4332-4341. (doi:10.1093/emboj/19.16.4332)

Brélivet Y, Rochel N \& Moras D 2011 Structural analysis of nuclear receptors: from isolated domains to integral proteins. Molecular and Cellular Endocrinology 348 466-473. (doi:10.1016/j.mce.2011.08.015)

Bulynko YA \& O'Malley BW 2011 Nuclear receptor coactivators: structural and functional biochemistry. Biochemistry 50 313-328. (doi:10.1021/ bi101762x)

Burakov D, Crofts LA, Chang C-PB \& Freedman LP 2002 Reciprocal recruitment of DRIP/mediator and p160 coactivator complexes in vivo by estrogen receptor. Journal of Biological Chemistry 277 14359-14362. (doi:10.1074/jbc.C200099200)

Cai G, Chaban YL, Imasaki T, Kovacs JA, Calero G, Penczek PA, Takagi Y \& Asturias FJ 2012 Interaction of the mediator head module with RNA polymerase II. Structure 20 899-910. (doi:10.1016/j.str.2012.02.023)

Cavaillès V, Dauvois S, L'Horset F, Lopez G, Hoare S, Kushner PJ \& Parker MG 1995 Nuclear factor RIP140 modulates transcriptional activation by the estrogen receptor. EMBO Journal 14 3741-3751.

Chalkiadaki A \& Guarente L 2012 Sirtuins mediate mammalian metabolic responses to nutrient availability. Nature Reviews. Endocrinology $\mathbf{8}$ 287-296. (doi:10.1038/nrendo.2011.225)

Chandra V, Huang P, Hamuro Y, Raghuram S, Wang Y, Burris TP \& Rastinejad F 2008 Structure of the intact PPAR- $\gamma-R X R-$ nuclear receptor complex on DNA. Nature 456 350-356. (doi:10.1038/nature07413)

Chandra V, Huang P, Potluri N, Wu D, Kim Y \& Rastinejad F 2013 Multidomain integration in the structure of the HNF- $4 \alpha$ nuclear receptor complex. Nature 495 394-398. (doi:10.1038/nature11966)

Chauchereau A, Amazit L, Quesne M, Guiochon-Mantel A \& Milgrom E 2003 Sumoylation of the progesterone receptor and of the steroid receptor coactivator SRC-1. Journal of Biological Chemistry $\mathbf{2 7 8}$ 12335-12343. (doi:10.1074/jbc.M207148200)

Chen JD \& Evans RM 1995 A transcriptional co-repressor that interacts with nuclear hormone receptors. Nature 377 454-457. (doi:10.1038/ 377454a0)

Ciferri C, Lander GC, Maiolica A, Herzog F, Aebersold R \& Nogales E 2012 Molecular architecture of human polycomb repressive complex 2. eLife 1 e00005. (doi:10.7554/eLife.00005)

Clapier CR \& Cairns BR 2009 The biology of chromatin remodeling complexes. Annual Review of Biochemistry 78 273-304. (doi:10.1146/ annurev.biochem.77.062706.153223)

Clements A, Rojas JR, Trievel RC, Wang L, Berger SL \& Marmorstein R 1999 Crystal structure of the histone acetyltransferase domain of the human PCAF transcriptional regulator bound to coenzyme A. EMBO Journal 18 3521-3532. (doi:10.1093/emboj/18.13.3521)

Cloos PAC, Christensen J, Agger K \& Helin K 2008 Erasing the methyl mark: histone demethylases at the center of cellular differentiation and 
disease. Genes and Development 22 1115-1140. (doi:10.1101/gad. 1652908)

Cosgrove MS 2012 Writers and readers: deconvoluting the harmonic complexity of the histone code. Nature Structural \& Molecular Biology 19 739-740. (doi:10.1038/nsmb.2350)

Dames SA, Martinez-Yamout M, De Guzman RN, Dyson HJ \& Wright PE 2002 Structural basis for Hif- $1 \alpha$ /CBP recognition in the cellular hypoxic response. PNAS 99 5271-5276. (doi:10.1073/pnas.082121399)

Delvecchio M, Gaucher J, Aguilar-Gurrieri C, Ortega E \& Panne D 2013 Structure of the p300 catalytic core and implications for chromatin targeting and HAT regulation. Nature Structural \& Molecular Biology 20 1040-1046. (doi:10.1038/nsmb.2642)

Dou Y, Milne TA, Tackett AJ, Smith ER, Fukuda A, Wysocka J, Allis CD, Chait BT, Hess JL \& Roeder RG 2005 Physical association and coordinate function of the H3 K4 methyltransferase MLL1 and the H4 K16 acetyltransferase MOF. Cell 121 873-885. (doi:10.1016/j.cell.2005. 04.031)

Eustermann S, Yang J-C, Law MJ, Amos R, Chapman LM, Jelinska C, Garrick D, Clynes D, Gibbons RJ, Rhodes D et al. 2011 Combinatorial readout of histone $\mathrm{H} 3$ modifications specifies localization of ATRX to heterochromatin. Nature Structural \& Molecular Biology 18 777-782. (doi:10.1038/nsmb.2070)

Fang R, Chen F, Dong Z, Hu D, Barbera AJ, Clark EA, Fang J, Yang Y, Mei P, Rutenberg M et al. 2013 LSD2/KDM1B and its cofactor NPAC/GLYR1 endow a structural and molecular model for regulation of H3K4 demethylation. Molecular Cell 49 558-570. (doi:10.1016/j.molcel.2012. 11.019)

Foulds CE, Feng Q, Ding C, Bailey S, Hunsaker TL, Malovannaya A, Hamilton RA, Gates LA, Zhang Z, Li C et al. 2013 Proteomic analysis of coregulators bound to $\mathrm{ER} \alpha$ on DNA and nucleosomes reveals coregulator dynamics. Molecular Cell 51 185-199. (doi:10.1016/ j.molcel.2013.06.007)

Gal-Yam EN, Saito Y, Egger G \& Jones PA 2008 Cancer epigenetics: modifications, screening, and therapy. Annual Review of Medicine 59 267-280. (doi:10.1146/annurev.med.59.061606.095816)

Gardner KE, Allis CD \& Strahl BD 2011 Operating on chromatin, a colorful language where context matters. Journal of Molecular Biology 409 36-46. (doi:10.1016/j.jmb.2011.01.040)

Gill G 2004 SUMO and ubiquitin in the nucleus: different functions, similar mechanisms? Genes and Development 18 2046-2059. (doi:10.1101/gad.1214604)

Girdwood D, Bumpass D, Vaughan OA, Thain A, Anderson LA, Snowden AW, Garcia-Wilson E, Perkins ND \& Hay RT 2003 P300 transcriptional repression is mediated by SUMO modification. Molecular Cell $\mathbf{1 1}$ 1043-1054. (doi:10.1016/S1097-2765(03)00141-2)

Goodson ML, Mengeling BJ, Jonas BA \& Privalsky ML 2011 Alternative mRNA splicing of corepressors generates variants that play opposing roles in adipocyte differentiation. Journal of Biological Chemistry 286 44988-44999. (doi:10.1074/jbc.M111.291625)

Grant PA, Duggan L, Côté J, Roberts SM, Brownell JE, Candau R, Ohba R, Owen-Hughes T, Allis CD, Winston F et al. 1997 Yeast Gcn5 functions in two multisubunit complexes to acetylate nucleosomal histones: characterization of an Ada complex and the SAGA (Spt/Ada) complex. Genes and Development 11 1640-1650. (doi:10.1101/gad.11.13.1640)

Gupta P, Huq MD, Khan SA, Tsai N-P \& Wei L-N 2005 Regulation of co-repressive activity of and HDAC recruitment to RIP140 by site-specific phosphorylation. Molecular and Cellular Proteomics 4 1776-1784. (doi:10.1074/mcp.M500236-MCP200)

Gururaj AE, Singh RR, Rayala SK, Holm C, Hollander den P, Zhang H, Balasenthil S, Talukder AH, Landberg G \& Kumar R 2006 MTA1, a transcriptional activator of breast cancer amplified sequence 3. PNAS 103 6670-6675. (doi:10.1073/pnas.0601989103)

Halachmi S, Marden E, Martin G, MacKay H, Abbondanza C \& Brown M 1994 Estrogen receptor-associated proteins: possible mediators of hormone-induced transcription. Science 264 1455-1458. (doi:10.1126/ science.8197458)
Han SJ, Hawkins SM, Begum K, Jung SY, Kovanci E, Qin J, Lydon JP, DeMayo FJ \& O'Malley BW 2012 A new isoform of steroid receptor coactivator-1 is crucial for pathogenic progression of endometriosis. Nature Medicine 18 1102-1111. (doi:10.1038/nm.2826)

Hauk G, McKnight JN, Nodelman IM \& Bowman GD 2010 The chromodomains of the Chd1 chromatin remodeler regulate DNA access to the ATPase motor. Molecular Cell 39 711-723. (doi:10.1016/j. molcel.2010.08.012)

He C, Li F, Zhang J, Wu J \& Shi Y 2013 The methyltransferase NSD3 has chromatin-binding motifs, PHD5-C5HCH, that are distinct from other NSD (nuclear receptor SET domain) family members in their histone H3 recognition. Journal of Biological Chemistry 288 4692-4703. (doi:10.1074/jbc.M112.426148)

Heery DM, Kalkhoven E, Hoare S \& Parker MG 1997 A signature motif in transcriptional co-activators mediates binding to nuclear receptors. Nature 387 733-736. (doi:10.1038/42750)

Helin K \& Dhanak D 2013 Chromatin proteins and modifications as drug targets. Nature 520 480-488. (doi:10.1038/nature12751)

Hörlein AJ, Näär AM, Heinzel T, Torchia J, Gloss B, Kurokawa R, Ryan A, Kamei Y, Söderstrom M \& Glass CK 1995 Ligand-independent repression by the thyroid hormone receptor mediated by a nuclear receptor co-repressor. Nature 377 397-404. (doi:10.1038/377397a0)

Hu X \& Lazar MA 1999 The CoRNR motif controls the recruitment of corepressors by nuclear hormone receptors. Nature $\mathbf{4 0 2} 93-96$. (doi:10.1038/47069)

Huang Y, Fang J, Bedford MT, Zhang Y \& Xu R-M 2006 Recognition of histone H3 lysine-4 methylation by the double tudor domain of JMJD2A. Science 312 748-751. (doi:10.1126/science.1125162)

Jacobs SA \& Khorasanizadeh S 2002 Structure of HP1 chromodomain bound to a lysine 9-methylated histone H3 tail. Science 295 2080-2083. (doi:10.1126/science.1069473)

Jeyakumar M, Tanen MR \& Bagchi MK 1997 Analysis of the functional role of steroid receptor coactivator-1 in ligand-induced transactivation by thyroid hormone receptor. Molecular Endocrinology 11 755-767. (doi:10.1210/me.11.6.755)

Joshi P, Greco TM, Guise AJ, Luo Y, Yu F, Nesvizhskii AI \& Cristea IM 2013 The functional interactome landscape of the human histone deacetylase family. Molecular Systems Biology 9 672. (doi:10.1038/msb.2013.26)

Kelly RD \& Cowley SM 2013 The physiological roles of histone deacetylase (HDAC) 1 and 2: complex co-stars with multiple leading parts. Biochemical Society Transactions 41 741-749. (doi:10.1042/ BST20130010)

Khorasanizadeh S \& Rastinejad F 2001 Nuclear-receptor interactions on DNA-response elements. Trends in Biochemical Sciences 26 384-390. (doi:10.1016/S0968-0004(01)01800-X)

Kugel JF \& Goodrich JA 2012 Non-coding RNAs: key regulators of mammalian transcription. Trends in Biochemical Sciences 37 144-151. (doi:10.1016/j.tibs.2011.12.003)

Lahm A, Paolini C, Pallaoro M, Nardi MC, Jones P, Neddermann P, Sambucini S, Bottomley MJ, Surdo Lo P, Carfí A et al. 2007 Unraveling the hidden catalytic activity of vertebrate class IIa histone deacetylases. PNAS 104 17335-17340. (doi:10.1073/pnas.0706487104)

Lee KK \& Workman JL 2007 Histone acetyltransferase complexes: one size doesn't fit all. Nature Reviews. Molecular Cell Biology 8 284-295. (doi:10.1038/nrm2145)

Lindroth AM, Shultis D, Jasencakova Z, Fuchs J, Johnson L, Schubert D, Patnaik D, Pradhan S, Goodrich J, Schubert I et al. 2004 Dual histone H3 methylation marks at lysines 9 and 27 required for interaction with CHROMOMETHYLASE3. EMBO Journal 23 4286-4296. (doi:10.1038/ sj.emboj.7600430)

Liu Y, Chen W, Gaudet J, Cheney MD, Roudaia L, Cierpicki T, Klet RC, Hartman K, Laue TM, Speck NA et al. 2007 Structural basis for recognition of SMRT/N-CoR by the MYND domain and its contribution to AML1/ETO's activity. Cancer Cell 11 483-497. (doi:10.1016/j.ccr. 2007.04.010)

Published by Bioscientifica Ltd 
Liu X, Wang L, Zhao K, Thompson PR, Hwang Y, Marmorstein R \& Cole PA 2008 The structural basis of protein acetylation by the p300/СBP transcriptional coactivator. Nature $\mathbf{4 5 1}$ 846-850. (doi:10.1038/ nature06546)

Lonard DM \& O'Malley BW 2007 Nuclear receptor coregulators: judges, juries, and executioners of cellular regulation. Molecular Cell 27 691-700. (doi:10.1016/j.molcel.2007.08.012)

Lonard DM \& O'Malley BW 2012 Nuclear receptor coregulators: modulators of pathology and therapeutic targets. Nature Reviews. Endocrinology 8 598-604. (doi:10.1038/nrendo.2012.100)

Makde RD, England JR, Yennawar HP \& Tan S 2010 Structure of RCC1 chromatin factor bound to the nucleosome core particle. Nature $\mathbf{4 6 7}$ 562-566. (doi:10.1038/nature09321)

Margueron R, Justin N, Ohno K, Sharpe ML, Son J, Drury WJ, Voigt P, Martin SR, Taylor WR, De Marco V et al. 2009 Role of the polycomb protein EED in the propagation of repressive histone marks. Nature $\mathbf{4 6 1}$ 762-767. (doi:10.1038/nature08398)

Martin M, Kettmann R \& Dequiedt F 2007 Class IIa histone deacetylases: regulating the regulators. Oncogene 26 5450-5467. (doi:10.1038/sj.onc. 1210613)

Matsumura H, Kusaka N, Nakamura T, Tanaka N, Sagegami K, Uegaki K, Inoue T \& Mukai Y 2012 Crystal structure of the N-terminal domain of the yeast general corepressor Tup1p and its functional implications. Journal of Biological Chemistry 287 26528-26538. (doi:10.1074/jbc. M112.369652)

Métivier R, Penot G, Hübner MR, Reid G, Brand H, Kos M \& Gannon F 2003 Estrogen receptor- $\alpha$ directs ordered, cyclical, and combinatorial recruitment of cofactors on a natural target promoter. Cell $\mathbf{1 1 5}$ 751-763. (doi:10.1016/S0092-8674(03)00934-6)

Millard CJ, Watson PJ, Celardo I, Gordiyenko Y, Cowley SM, Robinson CV, Fairall L \& Schwabe JW 2013 Class I HDACs share a common mechanism of regulation by inositol phosphates. Molecular Cell $\mathbf{5 1}$ 1-11. (doi:10.1016/j.molcel.2013.05.020)

Mostaqul Huq MD, Gupta P, Tsai N-P, White R, Parker MG \& Wei L-N 2006 Suppression of receptor interacting protein 140 repressive activity by protein arginine methylation. EMBO Journal 25 5094-5104. (doi:10.1038/sj.emboj.7601389)

Mottis A, Mouchiroud L \& Auwerx J 2013 Emerging roles of the corepressors NCoR1 and SMRT in homeostasis. Genes and Development 27 819-835. (doi:10.1101/gad.214023.113)

Murzina NV, Pei X-Y, Zhang W, Sparkes M, Vicente-Garcia J, Pratap JV, McLaughlin SH, Ben-Shahar TR, Verreault A, Luisi BF et al. 2008 Structural basis for the recognition of histone $\mathrm{H} 4$ by the histonechaperone RbAp46. Structure 16 1077-1085. (doi:10.1016/j.str.2008. 05.006)

Nagy L, Kao HY, Love JD, Li C, Banayo E, Gooch JT, Krishna V, Chatterjee K, Evans RM \& Schwabe JW 1999 Mechanism of corepressor binding and release from nuclear hormone receptors. Genes \& Development $\mathbf{1 3}$ 3209-3216.

Nautiyal J, Christian M \& Parker MG 2013 Distinct functions for RIP140 in development, inflammation, and metabolism. Trends in Endocrinology and Metabolism 24 451-459. (doi:10.1016/j.tem.2013.05.001)

Nielsen PR, Nietlispach D, Mott HR, Callaghan J, Bannister A, Kouzarides T, Murzin AG, Murzina NV \& Laue ED 2002 Structure of the HP1 chromodomain bound to histone H3 methylated at lysine 9. Nature 416 103-107. (doi:10.1038/nature722)

Nolte RT, Wisely GB, Westin S, Cobb JE, Lambert MH, Kurokawa R, Rosenfeld MG, Willson TM, Glass CK \& Milburn MV 1998 Ligand binding and co-activator assembly of the peroxisome proliferatoractivated receptor- $\gamma$. Nature 395 137-143. (doi:10.1038/25931)

Oberoi J, Fairall L, Watson PJ, Yang J-C, Czimmerer Z, Kampmann T, Goult BT, Greenwood JA, Gooch JT, Kallenberger BC et al. 2011 Structural basis for the assembly of the SMRT/NCoR core transcriptional repression machinery. Nature Structural \& Molecular Biology 18177-184. (doi:10.1038/ nsmb.1983)
Onate SA, Tsai SY, Tsai MJ \& O’Malley BW 1995 Sequence and characterization of a coactivator for the steroid hormone receptor superfamily. Science 270 1354-1357. (doi:10.1126/science.270. 5240.1354)

Owen DJ, Ornaghi P, Yang JC, Lowe N, Evans PR, Ballario P, Neuhaus D, Filetici P \& Travers AA 2000 The structural basis for the recognition of acetylated histone $\mathrm{H} 4$ by the bromodomain of histone acetyltransferase gcn5p. ЕМВО Journal 19 6141-6149. (doi:10.1093/emboj/19.22.6141)

Peterson TJ, Karmakar S, Pace MC, Gao T \& Smith CL 2007 The silencing mediator of retinoic acid and thyroid hormone receptor (SMRT) corepressor is required for full estrogen receptor $\alpha$ transcriptional activity. Molecular and Cellular Biology 27 5933-5948. (doi:10.1128/ MCB.00237-07)

Phelan CA, Gampe RT, Lambert MH, Parks DJ, Montana V, Bynum J, Broderick TM, Hu X, Williams SP, Nolte RT et al. 2010 Structure of Rev-erb $\alpha$ bound to N-CoR reveals a unique mechanism of nuclear receptor-co-repressor interaction. Nature Structural \& Molecular Biology 17 808-814. (doi:10.1038/nsmb.1860)

Racki LR, Yang JG, Naber N, Partensky PD, Acevedo A, Purcell TJ, Cooke R, Cheng Y \& Narlikar GJ 2009 The chromatin remodeller ACF acts as a dimeric motor to space nucleosomes. Nature 462 1016-1021. (doi:10.1038/nature08621)

Ramírez J, Dege C, Kutateladze TG \& Hagman J 2012 MBD2 and multiple domains of $\mathrm{CHD} 4$ are required for transcriptional repression by Mi-2/NuRD complexes. Molecular and Cellular Biology 32 5078-5088. (doi:10.1128/MCB.00819-12)

Razeto A, Ramakrishnan V, Litterst CM, Giller K, Griesinger C, Carlomagno T, Lakomek N, Heimburg T, Lodrini M, Pfitzner E et al. 2004 Structure of the NCoA-1/SRC-1 PAS-B domain bound to the LXXLL motif of the STAT6 transactivation domain. Journal of Molecular Biology 336 319-329. (doi:10.1016/j.jmb.2003.12.057)

Rogatsky I 2001 Factor recruitment and TIF2/GRIP1 corepressor activity at a collagenase- 3 response element that mediates regulation by phorbol esters and hormones. EMBO Journal 20 6071-6083. (doi:10.1093/ emboj/20.21.6071)

Ruthenburg AJ, Li H, Patel DJ \& Allis CD 2007 Multivalent engagement of chromatin modifications by linked binding modules. Nature Reviews. Molecular Cell Biology 8 983-994. (doi:10.1038/nrm2298)

Shen X, Xiao H, Ranallo R, Wu W-H \& Wu C 2003 Modulation of ATPdependent chromatin-remodeling complexes by inositol polyphosphates. Science 299 112-114. (doi:10.1126/science.1078068)

Sheppard HM, Harries JC, Hussain S, Bevan C \& Heery DM 2001 Analysis of the steroid receptor coactivator 1 (SRC1)-CREB binding protein interaction interface and its importance for the function of SRC1. Molecular and Cellular Biology 21 39-50. (doi:10.1128/MCB.21.1. 39-50.2001)

Shi X, Hong T, Walter KL, Ewalt M, Michishita E, Hung T, Carney D, Peña P, Lan F, Kaadige MR et al. 2006 ING2 PHD domain links histone H3 lysine 4 methylation to active gene repression. Nature 442 96-99. (doi:10.1038/nature05140)

Song J-J, Garlick JD \& Kingston RE 2008 Structural basis of histone H4 recognition by p55. Genes and Development 22 1313-1318. (doi:10.1101/gad.1653308)

Stavreva DA, Varticovski L \& Hager GL 2012 Complex dynamics of transcription regulation. Biochimica et Biophysica Acta 1819 657-666. (doi:10.1016/j.bbagrm.2012.03.004)

Stavropoulos P, Blobel G \& Hoelz A 2006 Crystal structure and mechanism of human lysine-specific demethylase-1. Nature Structural \& Molecular Biology 13 626-632. (doi:10.1038/nsmb1113)

Steger DJ, Haswell ES, Miller AL, Wente SR \& O'Shea EK 2003 Regulation of chromatin remodeling by inositol polyphosphates. Science 299 114-116. (doi:10.1126/science.1078062)

Strahl BD \& Allis CD 2000 The language of covalent histone modifications. Nature 403 41-45. (doi:10.1038/47412)

Tagami T, Madison LD, Nagaya T \& Jameson JL 1997 Nuclear receptor corepressors activate rather than suppress basal transcription of genes 
that are negatively regulated by thyroid hormone. Molecular and Cellular Biology 17 2642-2648.

Teyssier C, Ma H, Emter R, Kralli A \& Stallcup MR 2005 Activation of nuclear receptor coactivator PGC- $1 \alpha$ by arginine methylation. Genes and Development 19 1466-1473. (doi:10.1101/gad.1295005)

Varlakhanova N, Hahm JB \& Privalsky ML 2011 Regulation of SMRT corepressor dimerization and composition by MAP kinase phosphorylation. Molecular and Cellular Endocrinology 332 180-188. (doi:10.1016/j.mce.2010.10.010)

Wang Q, Carroll JS \& Brown M 2005 Spatial and temporal recruitment of androgen receptor and its coactivators involves chromosomal looping and polymerase tracking. Molecular Cell 19 631-642. (doi:10.1016/ j.molcel.2005.07.018)

Wang L, Zuercher WJ, Consler TG, Lambert MH, Miller AB, Orband-Miller LA, McKee DD, Willson TM \& Nolte RT 2006 X-ray crystal structures of the estrogen-related receptor- $\gamma$ ligand binding domain in three functional states reveal the molecular basis of small molecule regulation. Journal of Biological Chemistry 281 37773-37781. (doi:10.1074/jbc.M608410200)

Wang Z, Zang C, Cui K, Schones DE, Barski A, Peng W \& Zhao K 2009 Genome-wide mapping of HATs and HDACs reveals distinct functions in active and inactive genes. Cell 138 1019-1031. (doi:10.1016/j.cell. 2009.06.049)

Wang F, Li G, Altaf M, Lu C, Currie MA, Johnson A \& Moazed D 2013 Heterochromatin protein Sir3 induces contacts between the amino terminus of histone H4 and nucleosomal DNA. PNAS 110 8495-8500. (doi:10.1073/pnas.1300126110)

Waters L, Yue B, Veverka V, Renshaw P, Bramham J, Matsuda S, Frenkiel T, Kelly G, Muskett F, Carr M et al. 2006 Structural diversity in p160/CREBbinding protein coactivator complexes. Journal of Biological Chemistry 281 14787-14795. (doi:10.1074/jbc.M600237200)

Watson PJ, Fairall L, Santos GM \& Schwabe JWR 2012a Structure of HDAC3 bound to co-repressor and inositol tetraphosphate. Nature $\mathbf{4 8 1}$ 335-340. (doi:10.1038/nature10728)

Watson PJ, Fairall L \& Schwabe JWR 2012b Nuclear hormone receptor co-repressors: structure and function. Molecular and Cellular Endocrinology 348 440-449. (doi:10.1016/j.mce.2011.08.033)

Weiss RE, Xu J, Ning G, Pohlenz J, O'Malley BW \& Refetoff S 1999 Mice deficient in the steroid receptor co-activator 1 (SRC-1) are resistant to thyroid hormone. EMBO Journal 18 1900-1904. (doi:10.1093/emboj/ 18.7.1900)

Wu P-YJ, Ruhlmann C, Winston F \& Schultz P 2004 Molecular architecture of the S. cerevisiae SAGA complex. Molecular Cell 15 199-208. (doi:10.1016/j.molcel.2004.06.005)

Wu R-C, Feng Q, Lonard DM \& O'Malley BW 2007 SRC-3 coactivator functional lifetime is regulated by a phospho-dependent ubiquitin time clock. Cell 129 1125-1140. (doi:10.1016/j.cell.2007.04.039)
Wurtz JM, Bourguet W, Renaud JP, Vivat V, Chambon P, Moras D \& Gronemeyer H 1996 A canonical structure for the ligand-binding domain of nuclear receptors. Nature Structural Biology 3 87-94. (doi:10.1038/nsb0196-87)

Xu W, Chen H, Du K, Asahara H, Tini M, Emerson BM, Montminy M \& Evans RM 2001 A transcriptional switch mediated by cofactor methylation. Science 294 2507-2511. (doi:10.1126/science.1065961)

Xu HE, Stanley TB, Montana VG, Lambert MH, Shearer BG, Cobb JE, McKee DD, Galardi CM, Plunket KD, Nolte RT et al. 2002 Structural basis for antagonist-mediated recruitment of nuclear co-repressors by PPAR $\alpha$. Nature 415 813-817. (doi:10.1038/415813a)

Yamada K, Frouws TD, Angst B, Fitzgerald DJ, DeLuca C, Schimmele K, Sargent DF \& Richmond TJ 2011 Structure and mechanism of the chromatin remodelling factor ISW1a. Nature 472 448-453. (doi:10.1038/nature09947)

Yan Y, Barlev NA, Haley RH, Berger SL \& Marmorstein R 2000 Crystal structure of yeast Esa1 suggests a unified mechanism for catalysis and substrate binding by histone acetyltransferases. Molecular Cell $\mathbf{6}$ 1195-1205. (doi:10.1016/S1097-2765(00)00116-7)

Yang X-J \& Seto E 2007 HATs and HDACs: from structure, function and regulation to novel strategies for therapy and prevention. Oncogene 26 5310-5318. (doi:10.1038/sj.onc.1210599)

Yang M, Gocke CB, Luo X, Borek D, Tomchick DR, Machius M, Otwinowski Z $\&$ Yu H 2006 Structural basis for CoREST-dependent demethylation of nucleosomes by the human LSD1 histone demethylase. Molecular Cell 23 377-387. (doi:10.1016/j.molcel.2006.07.012)

Yang M, Culhane JC, Szewczuk LM, Gocke CB, Brautigam CA, Tomchick DR, Machius M, Cole PA \& Yu H 2007 Structural basis of histone demethylation by LSD1 revealed by suicide inactivation. Nature Structural \& Molecular Biology 14 535-539. (doi:10.1038/nsmb1255)

Yang D, Fang Q, Wang M, Ren R, Wang H, He M, Sun Y, Yang N \& Xu R-M $2013 \mathrm{~N} \alpha$-acetylated Sir3 stabilizes the conformation of a nucleosomebinding loop in the BAH domain. Nature Structural \& Molecular Biology 20 1116-1118. (doi:10.1038/nsmb.2637)

Yuan H \& Marmorstein R 2013 Histone acetyltransferases: rising ancient counterparts to protein kinases. Biopolymers 99 98-111. (doi:10.1002/ bip.22128)

Zeng L, Zhang Q, Gerona-Navarro G, Moshkina N \& Zhou M-M 2008 Structural basis of site-specific histone recognition by the bromodomains of human coactivators PCAF and CBP/p300. Structure $\mathbf{1 6}$ 643-652. (doi:10.1016/j.str.2008.01.010)

Zhang Y, Ng H-H, Erdjument-Bromage H, Tempst P, Bird A \& Reinberg D 1999 Analysis of the NuRD subunits reveals a histone deacetylase core complex and a connection with DNA methylation. Genes and Development 13 1924-1935. (doi:10.1101/gad.13.15.1924)

Received in final form 10 October 2013

Accepted 15 October 2013 http://jme.endocrinology-journals.org DOI: 10.1530/JME-13-0227
() 2013 Society for Endocrinology Printed in Great Britain
Published by Bioscientifica Ltd 